山階鳥研報 (J. Yamashina Inst. Ornith.), 16: 172-173, 1984

\title{
見島におけるムジセッカの日本初記録
}

小林繁樹・梶畑哲二・長野時彦・平林輝 美

\section{The First Record for Philloscops fuscatus in Japan}

\author{
Shigeki Kobayashi*1, Tetsuzi Kajihata*2, Tokihiko Nagano*3 \\ and Terumi Hirabayashi*4
}

\begin{abstract}
Between May 3 and 6, 1984, the authers did bird banding work on Mishima, an isolated island about $45 \mathrm{~km}$ north-west of Hagi City, Yamaguchi Prefecture. During the period, they caught a Dusky Warbler Philloscops fuscatus which had been never recorded in Japan. The bird was mesured, photographed and then released.
\end{abstract}

見島は, 山口県萩市の北西約 $45 \mathrm{~km}$ の日本海に浮かぶ孤島で, 面積 $7.90 \mathrm{~km}^{2}$ 。島はほぼ三 角状で南北 $4.7 \mathrm{~km}$, 東西 $3.0 \mathrm{~km}$ 程である。

1984 年 5 月 3 日から 6 日までの間, 同島において鳥類標識調査中, 日本で未記録のムジ セッカ Philloscops fuscatus を捕獲したので, 以下に報告する。なおこの鳥は計測, 写真撮影 の後, 足環はつけずに放鳥した。

報告するにあたって, 山階鳥類研究所標識研究室の尾崎清明氏に本種の同定及び本文作成の 上で助言をいただいた。また武下雅文氏には写真を使用させていただいた。誌上を借りてお礼 申し上げる。

なお，上記調査者は，いずれも環境庁長官より鳥類捕獲許可証（No.678 他）を取得してい る。

1. 捕獲日時・場所：1984 年 5 月 5 日午前 9 時頃。山口県萩市見島本村アマメ, 標高 50 $\mathrm{m}$ 程の海岸近くの水田, 畑地帯。畑のまわりには風よけ用のマッとメダケのブッシュがある。

2. 測定值・特徵：翼長（最大） $59 \mathrm{~mm}$, 尾長 $44 \mathrm{~mm}$, 露出嘴峰 $7.7 \mathrm{~mm}$, 跗蹠 $22.3 \mathrm{~mm}$, 全長 $113.5 \mathrm{~mm}$ 。頭部と背面および翼は灰褐色からオリーブ色で翼帯はない。眉斑は赤黄色味 をおびた褐色。上嘴は黒く, 下嘴は黄土色。尾羽は 12 枚。下面の中央は白色で, まわりは黄 色味をおびる。足裏はカラシ色。写真撮影中にチャッ, チャッと鳴いた。

3. 考察: 本種は, 東部シベリア, 中国四川省, 北満州及びカラフトで繁殖し, 冬期にはイ ンドシナ半島, 中国大陸南部, インド東北部に渡って越冬する（山階 1980）。台湾でも冬期少 数が渡来するといわれており（小林汪か 1981），今回記録の鳥は，越冬地から繁殖地に向かう 渡りの途中に，日本海に出て見島に迷行したものと思われる。なお，見島では 1978 年 5 月

\footnotetext{
Recieved 25 June 1984

*1 Kuriyakaisaku minami 773-16, Tokuyama-shi, 745 Japan

*2 Chohumiyazaki-cho 4-12, Shimonoseki-shi, 752 Japan

*3 Nukushina 3-2-26, Higashi-ku, Hiroshima-shi, 735 Japan

*4 c/o Mitsunaga, Tomitahara 3-13, Yamaguchi-shi, 753 Japan
} 


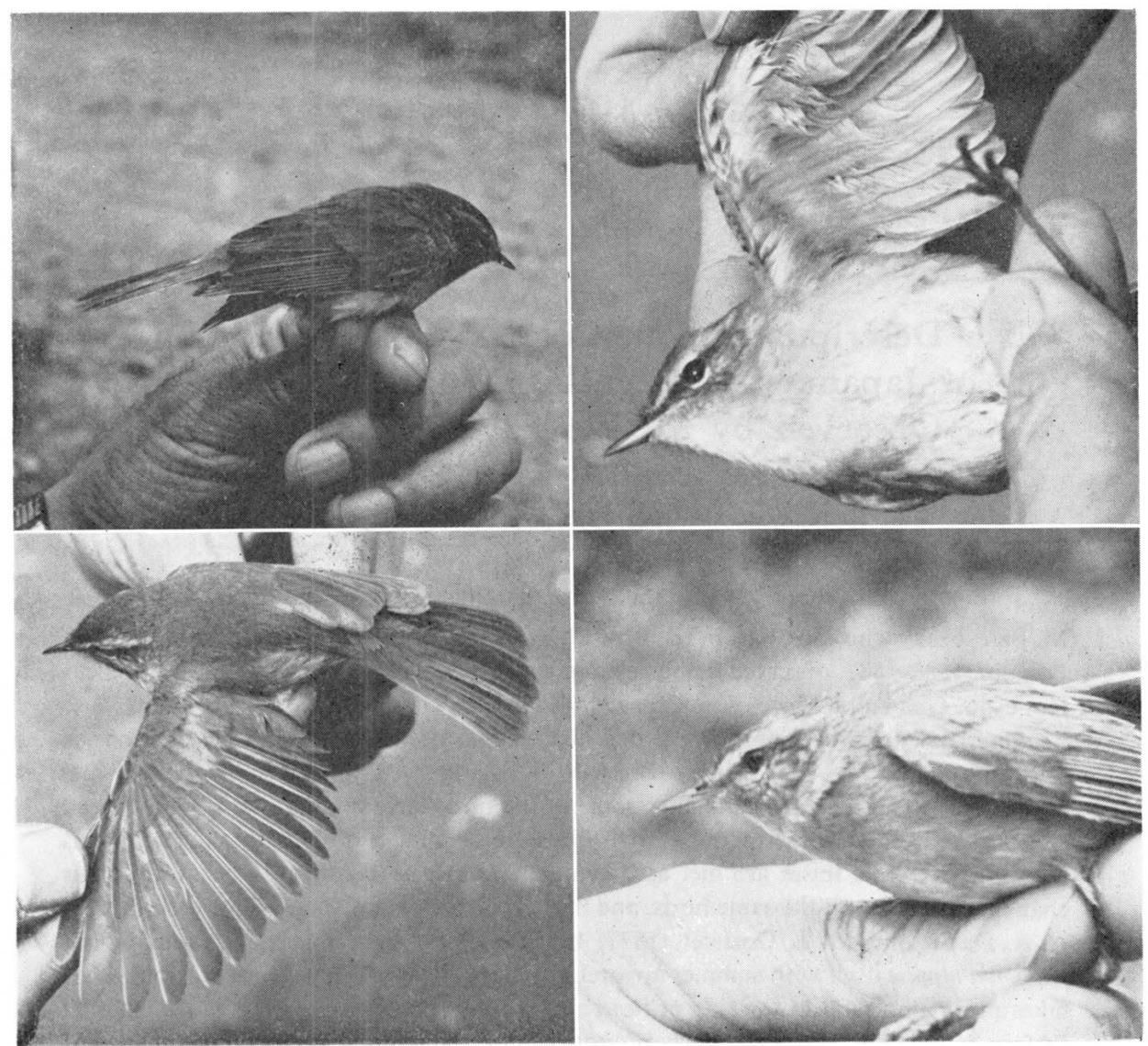

Fig. 1. Dusky Warbler Philloscops fuscatus (Photo by M. Takeshita \& S. Kobayashi)

3 日に未確認の観察記録がある（北九州野鳥の会 1978）。

\section{引用文 献}

北九州野鳥の会 1978 . 山口県見島の鳥類. $46 \mathrm{p}$. 北九州市.

小林桂助, 張 英彦 1981。台湾鳥類図鑑 前田グラフィック・アーッ, 京都.

山階芳縻 1980, 日本の鳥類と其生態 (復刻版). 出版科学総合研究所.

小林繁樹: $\overline{7} 745$ 徳山市栗屋開作南 773-16

梶畑哲二: 于752 下関市長府宮崎町 4-12

長野時彦: 7735 広島市東区温品 3-2-26

平林輝美：干753 山口市富田原 3-13 光永方 